\title{
CYTOGENETIC STUDIES ON TWO RUBUS ARCTICUS-HYBRIDS.
}

\author{
by \\ ANTERo VAarama \\ State Horticultural Institute, Piikkiö, Finland.
}

Received 5. 5. 1948.

Introduction.

The studies made hitherto have already elucidated many details of the cytogenetics of the wide and varying genus Rubus. This is seen for instance from the monograph on the section Eubati by Gustafsson (7) and the short survey on the cytogenetics of the genus Rubus by Clausen, Keck and Hiesey (1). We are, however, far from having a complete picture of the evolutionary relations of the different groups belonging to this genus. For instance the section Cylactis is so far for the most part unknown. The only study on this section is furnished by my earlier paper (19), dealing with the meiosis of the spontaneous hybrid $R$. caesius $\times$ saxatilis and the somatic chromosomes of a number of species and hybrids belonging to this section. ${ }^{1}$ )

The section Cylactis has, however, an important position in the investigation of the evolution of the genus. Certain species of this section may also become important as cultivated plants. This is especially probable of R.arcticus, circumpolar in the northern hemisphere, and in Finland one of the most sought-after forest berries owing to its delicious aroma. The cultivation of this species presents several difficulties, and the breeding work must therefore be based on hybridization with other Rubus species.

The present study deals with the cytogenetics of two R.arcticus hybrids, viz. R.idaeus $\times$ arcticus (R.binatus Lindb. fil.) and $R$. saxatilis $\times$ arcticus (R.castoreus Laest.) in the light of the meiosis in PMC and of the phenomena observed in the $\mathrm{F}_{2}$-generation of the former hybrid.

1 Rubus humulifolius C. A. Mey has been erroneously determined as tetraploid with $2 \mathrm{n}=28$. Actually this species is diploid with $2 \mathrm{n}=14$ chromosomes. 

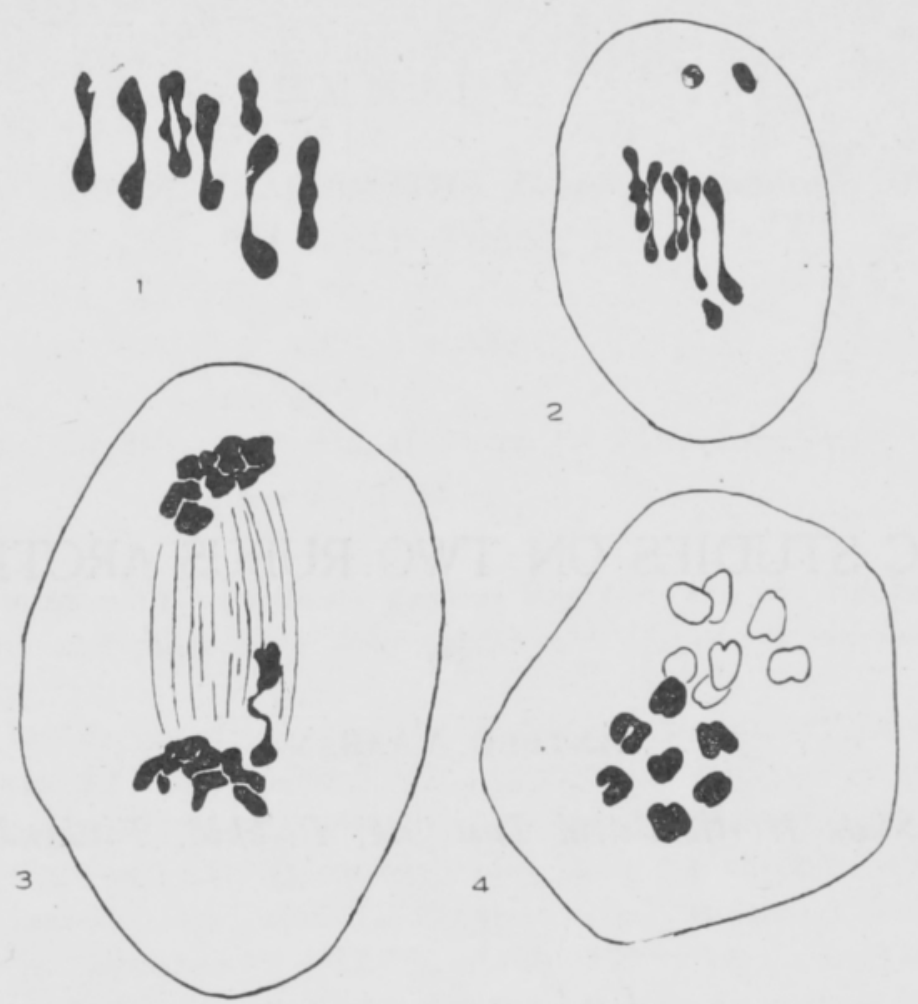

Figs 1-4. PMC of the hybrid $R$ ubus idaeus $\times$ arcticus. - Fig. 1. 7 separately drawn bivalents from a regular first metaphase. Fig. 2 First metaphase side view with 6 bivalents and 2 univalents. - Fig. 3. First anaphase. A lagging bivalent beside the lower chromosome group. - Fig. 4. A regular second metaphase. $-\times 3200$.

\section{Material and methods.}

The hybrid R.idaeus $\times$ arcticus has been made artificially by Mr. O. PoHJANheimo at the initiative of Prof. O. Meurman at the State Horticultural Institute. Wild R.idaeus strains growing around the Institute were crossed with wild R.articus strains from Central Finland. R.saxatilis $\times$ arcticus is a spontaneous hybrid which has been cultivated for many years in the Botanical Garden of Helsinki University. Its origin is, however, unknown.

The flower bud material has been fixed partly with Benda fluid, partly with craf solution, using Carnoy solution as a prefixative. For staining, crystal violet has been used.

$$
\begin{gathered}
\text { Meiosis in the hybrids. } \\
F_{1} \text {-generation of Rubus idaeus } \times \text { arcticus. }
\end{gathered}
$$

The somatic chromosome number of the hybrid has been found to be the same as in the parent species, viz. $2 \mathrm{n}=14$.

In most cases chromosome pairing is complete and 7 bivalents are formed (Fig. 1). The bivalents contain as a rule one chiasma, rarely two, which generally 
show complete terminalisation (Figs 1 and 2). Sometimes only six bivalents are formed, two chromosomes remaining as univalents (Fig. 2). In a number of cases when pairing is complete one bivalent may already come to lie outside the spindle at metaphase, or it is seen lagging in anaphase (Fig. 3). Such a bivalent is often eliminated or it goes undivided to one pole.

An analysis of 151 first metaphase side views showed that in $83,4 \%$ of the cells 7 bivalents occurred, the division being quite regular. Six bivalents and two univalents were found in $10,6 \%$ of the cells and an abnormally dividing bivalent in $6,0 \%$.

To find out the variation in the chromosome number caused by the observed irregularities, the chromosome number was determined from 118 late meiotic anaphase groups. The chromosome numbers were as follows:

\begin{tabular}{|c|c|c|c|}
\hline Chromosome number $\ldots \ldots \ldots \ldots$. & 8 & 7 & 6 \\
\hline Number of cases ............. & 8 & 89 & 10 \\
\hline Per cent $\ldots \ldots \ldots$ & 6.8 & 83.9 & 8.5 \\
\hline
\end{tabular}

The second division was almost without exception regular (Fig. 4). The formation of the pollen grains was also quite normal.

\section{$F_{2}$-generation in Rubus idaeus $\times$ arcticus.}

Owing to the dry summer of 1947 it was impossible to obtain good material. The buds of the plants which had suffered from drought fixed very badly. Fairly satisfactory material was obtained from a few individuals only and it showed that meiosis in the PMC is quite regular. Its course does not differ in any way from the meiosis of the diploid parent species.

\section{Rubus saxatilis $\times$ arcticus.}

The somatic chromosome number of this hybrid is $2 \mathrm{n}=21$ (19). Its chromosome complement contains two basic chromosome sets from the tetraploid R.saxatilis and one from the diploid R.arcticus. In meiosis it is seen that these three sets are so homologous that pairing can take place between the units of the different sets. The formation of trivalents is fairly frequent. In addition there occur a number of bivalents and univalents (Fig. 5).

The analysis of 20 first metaphase side views gave the following frequencies for the different configurations.

$\begin{array}{lccc} & \text { Univ. } & \text { Biv. } & \text { Triv. } \\ \text { Variation } \ldots \ldots \ldots \ldots \ldots \ldots & 2-8 & 3-8 & 0-4 \\ \text { Average per ceil } \ldots \ldots \ldots \ldots & 4.09 & 4.07 & 2.25\end{array}$



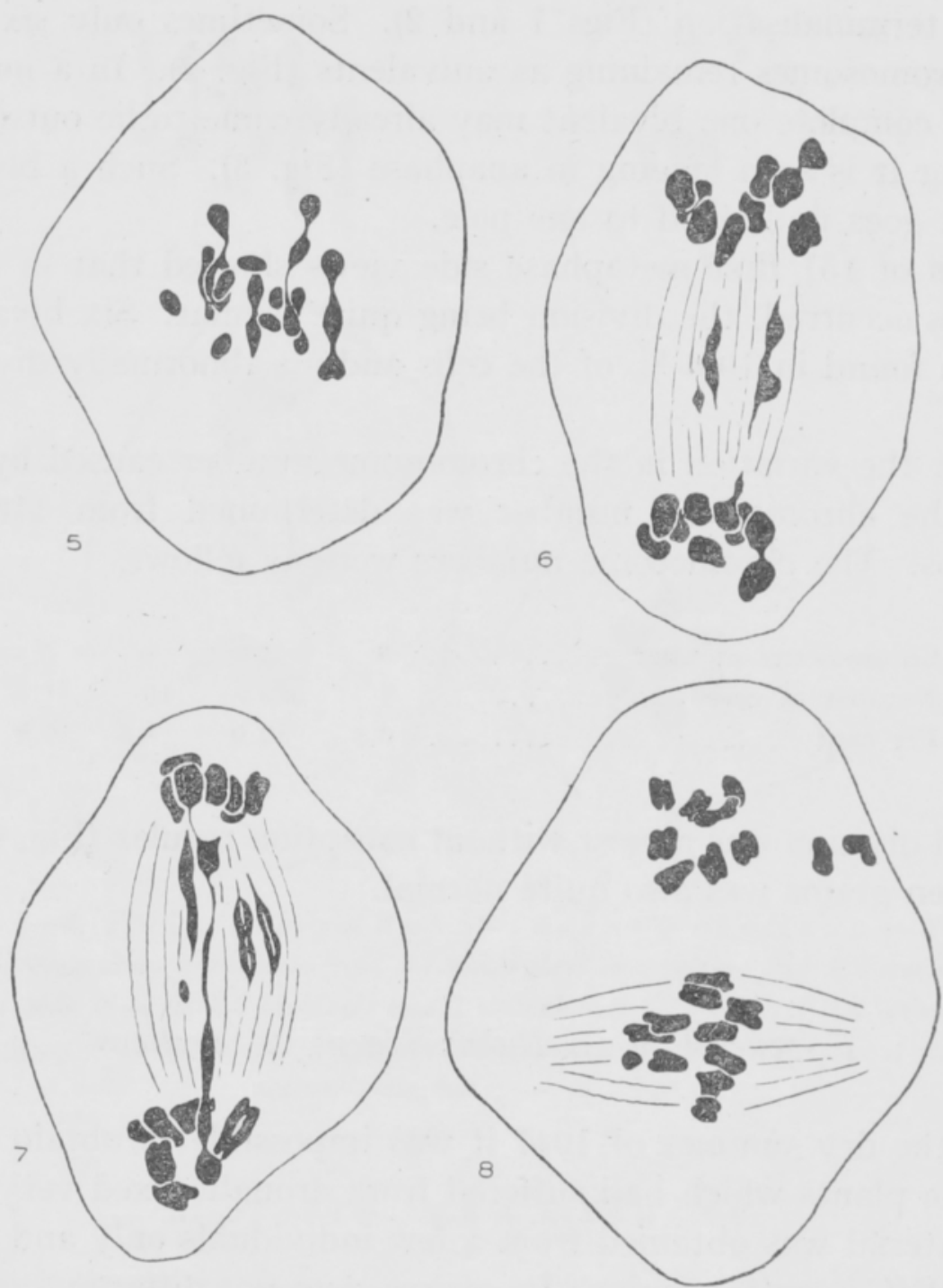

Figs 5-8. PMC of the hybrid $R$ ubus saxatilis $\times$ arcticus. - Fig. 5. First metaphase side view. 3 trivalents 3 bivalents and 6 univalents. - Fig. 6. First anaphase. Lagging trivalents and a fragment. - Fig. 7. First anaphase. Inversion bridge with a fragment and two lagging bivalents. - Fig. 8. Second metaphase. Different chromosome numbers in the plates. Two eliminated chromosomes. -- $\times 3200$.

If we compare these values with those obtained from the autotriploid R.idaeus $(18$, p. 144) it is seen that the number of bivalents and univalents in the present hybrid is clearly greater, the number of trivalents correspondingly smaller. This shows that the hybrid complement is not comparable with the autotriploid.

In anaphase it is seen that in particular the division of the trivalents is disturbed and hampered. When the other chromosomes have already reached the poles one or more trivalents are still in the middle of the spindle (Figs 6 and 7 ). These lagging trivalents divide so late that they are often eliminated. When the trivalents divide true inversion bridges with the adjoining fragments are often formed (Figs 6 and 7). The undivided univalents are as a rule distributed at random to the two poles. In certain cases bivalents are also seen to divide too late at the first division (Fig. 7). 
The number of chromosomes in the first division anaphase groups varies. The second division is fairly regular but elimination of the chromosomes may take place (Fig. 8). The eliminated chromosomes often form micronuclei. At pollen grain formation pentads and heptads are formed in addition to tetrads. The pollen grains are accordingly very variable in size.

$$
\text { Fertility of the hybrids. }
$$

The $\mathrm{F}_{1}$-generation of R.idaeus $\times$ arcticus begins to flower in the middle of June, and continues to do so during the whole season. When the autumn frosts begin in October the plants are still developing flowers and buds. The flowering season is thus longer and the flowering more abundant than in either of the parent species (cf. 4).

Despite their abundant flowering the plants are quite sterile during the whole summer. A certain amount of fruit formation begins to occur at the end of the growing season in September. Then fruits are formed which usually contain $1-4$, sometimes even 10 , druplets.

The causes of this sterility are not simple. The pollen of the hybrid is poor in quality. From an orcein-glycerin preparation $29.2 \%$ good pollen was counted. A germination test (48 hrs in $15 \%$ sucrose solution) gave $14.8 \%$ germinating grains. As the percentage of good pollen is so small in spite of the fact that the course of the meiosis is surprisingly regular, the question arises of whether we have here a case of haplontic or diplontic sterility.

It seems probable that a certain amount of haplontic sterility must be present. The irregularities observed in meiosis may give rise to inviable gametes having unbalanced chromosome numbers. In addition the inviability of gametes may be caused by small structural changes in the chromosomes (16). As will be described later, the existence of such "cryptic structural hybridity" in R.idaeus $\times$ arcticus is very probable.

The seasonal character of the fruit-formation shows, however, that the sterility cannot be exclusively haplontic. The observations indicate that the stamens and the pollen of the hybrid suffer badly from drought. During summer the majority of the anthers are not dehiscent. Accordingly no pollen is available for fertilization. In autumn when the relative humidity of the air is higher the anthers become more dehiscent and fertilization is to a certain degree possible.

The fruit formation of the one parent species R.arcticus shows, at least in Fennoscandia, a number of peculiar and so far unexplicable features. The fruit formation is abundant in Finland in a restricted area in the middle of the country. Outside this area the species is either sterile or forms fruit very rarely in spite of abundant flowering (14). For the present it cannot be decided whether the seasonal sterility of R.idaeus $\times$ arcticus has any connection with the regional variation of the fertility shown by R.arcticus. 
Some new light is thrown on the question of the sterility of the hybrid by the kind information given by an enthusiastic amateur horticulturist, Mr. KurT H. Envald (Kuopio, Finland). He has crossed the raspberry variety Bramleys Seedling with R.arcticus, and obtained a $\mathrm{F}_{1}$-generation which is highly fertile forming fruit during the whole summer.

We might suppose that the sterility of the $\mathrm{F}_{1}$-hybrid here studied - which in accordance with its mode of occurrence might tentatively be called seasonal sterility - is due to the hybrid gene combination. This combination seems to make the sexual organs very susceptible to extrinsic disturbances. If such a combination is not formed the hybrid is fertile. The seasonal sterility now described thus represents a special case of diplontic sterility (cf. 12).

As the seeds of various Rubus species as a rule germinate very poorly, it is difficult to estimate whether zygotic sterility occurs in the $F_{1}$-generation. In the $\mathrm{F}_{1}$-generation $30-40 \%$ of the seeds germinate. Since the $\mathrm{F}_{2}$-generation contained one dwarflike individual which reached a height of only $5 \mathrm{~cm}$ and subsequently died, we may suppose that completely lethal gene combinations too must occur.

In those individuals of the $\mathrm{F}_{2}$-generation which flowered in summer 1947, the fertility seemed to be restored to a great extent. Only one individual which morphologically most resembled R.arcticus. remained quite sterile. Owing to the dry summer the final estimation of fertility is still lacking. The pollen in all the flowering individuals was on an average similar to that in the parent species, when estimated from orcein-glycerin preparations. Germination tests have not been carried out.

The lenght of the flowering season and the abundance of the flowers in $R$. saxatilis $\times$ arcticus is about the same as in R.saxatilis. No seed-formation has been observed in the plants cultivated in the garden or growing in the wild, which have been examined by the author. This does not exclude the possibility that seeds could sometimes be formed. In orcein-glycerin preparations $95 \%$ empty pollen was found. The sterility shown by R.saxatilis $\times$ arcticus is obviously haplontic in character.

Segregation of species characters in the F $F_{2}$ eneration
of Rubus idaeus $\times$ arcticus.

The artificial R.idaeus $\times$ arcticus represents in gross observation an intermediate type between the parent species. As to its morphology it is very similar to the two spontaneous hybrid individuals which have been described by LINDBERG (10) from Finland. The intermediate character of the plant is seen, for instance, in the height, leaf-form, colour of the undersurface of the leaf, the form of the stipules, the colour of the petals and the aroma of the fruit. In regard to a number of characters the one or the other parent species showed clear dominance.

The following characters of R.arcticus prevail in the hybrid: oblong-ovate form of the bud and flowering of the first year shoots. The shoots live, however, two years in accordance with R.idaeus. These two characters combined result 
in the flowering of the hybrid shoots in two subsequent years. The stem as a rule is not aculeate, a feature similar to R.arcticus. The dominance is, however, not complete in that many shoots show a small number of thin pink prickles. As the form, colour and number of the prikles in R.idaeus vary greatly in natural population and the characters of the parent species are not known, the actual degree of dominance in the hybrid cannot be determined accurately.

From seed of the $\mathrm{F}_{1}$-hybrid collected late in the autumn of $194531 \mathrm{~F}_{2}$-plants were raised in the following summer. The seed resulted from free pollination. Since the seed had, however, developed late in the autumn when both the parent species had already ceased to flower, it may be regarded as certain that self-pollination had taken place.

The somatic chromosome number in 30 plants was found to be the same as in the $\mathrm{F}_{1}$-generation, viz. $2 \mathrm{n}=14$. One individual was triploid $2 \mathrm{n}=21$. This shows that unreduced gametes may be formed in the $\mathrm{F}_{1}$-generation. In the PMC this evidently must be very rare, since morphological examination of the pollen did not reveal any giant grains which could be thought to possess the diploid chromosome number. Unreduced gametes have, however, been found in the genus Rubus $(2,7)$. The triploid individual which, at least in its first stages, resembled the $\mathrm{F}_{1}$-hybrid, died during the first summer.

In the individuals of the $\mathrm{F}_{2}$-generation a segregation of the parental characters has taken place. Several individuals represent the peridaeus type, resembling $R$. idaeus closely even in gross observation. Segregation towards the perarcticus type is much rarer. Only one individual may be included in this type. And even in this case the morphological similarity is not very close. About one half of the $\mathrm{F}_{2}$-generation resembles in its main features the intermediate $\mathrm{F}_{1}$-generation.

A genetical analysis of the numerous characters which separate these two species, which taxonomically stand widely apart, would naturally be of great interest in regard to the problem of speciation. Since chromosome conjugation and chiasma formation are almost normal the $\mathrm{F}_{2}$-generation might possibly show Mendelian segregation, like other species hybrids in which meiosis resembles R. idaeus $\times$ arcticus, e.g. Antirrhinum (9) and Pafaver (4). Since the parent species have not been sufficiently analysed genetically, and especially as the genetical constitution of the actual parent strains is unknown, it has not been possible to carry out a complete analysis.

Even the present material has, however, afforded an apportunity for a number of observations. For the sake of comparison I have analysed the variation of certain characters in natural $R$. idaeus populations. This has been carried out in that a few individuals have been analysed from every $R$. idaeus population growing on an area of 80 hectares surrounding the State Horticultural Institute. The analysed individuals, 117 in number, all belong to different clones.

$R$. arcticus and $R$. idaeus differ very conspicuously in regard to the flower colour, the former having bright red, the latter white flowers. The hybrid flowers are of an intermediate pink colour, looking as if the colour difference might depend on one gene pair. The flowers in the $\mathrm{F}_{2}$-generation are, however, uniformly white. 
This cannot in my opinion be explained except on the assumption that the petal colour is a result of the combined action of the colour genes and a number of modifier genes acting in the same direction (cf. 15, p. 268).

This case is comparable to the Gossypium hybrids studied by HarLand (8) in regard to the inheritance of the petal spot. He found an intermediate dominance in the $\mathrm{F}_{1}$-generation, the segregation in $\mathrm{F}_{2}$-generation being, however, very irregular. In accordance with HARLAND we might suppose in the present case that the intermediate inheritance is a result of the haplo-insufficiency of the gene complex of $R$. arcticus. The disappearance of the red colour in the $\mathrm{F}_{2}$-generation again is brought about by the breakdown of the modifier system due to the anaphase segregation of he chromosomes. It is possible that the red colour of the petals cannot be formed after this breakdown.

It may be that the aroma specific for $R$. arcticus is inherited in the same manner. The $\mathrm{F}_{1}$-generation has an intermediate aroma which seems to disappear in the $\mathrm{F}_{2}$-generation. Owing to the dry summer the determination of the real aroma of the fruit has not been exact. It may be mentioned that according to Dr. R. Tuomikoski the berries of $R$. arcticus growing in Canada, in western Labrador, lack the typical aroma. In certain regions in Finland also aromaless clones seem to grow.

A character which is absent in $R$. arcticus, but which is regarded as characteristic for $R$. idaeus is the waxy bloom of the shoots. Lewis (11) has found that this character in the cultivated $R$. idaeus forms depends on one gene pair $\mathrm{Bd}$. This waxy bloom seems, however, to be very variable both in the $\mathrm{F}_{2}$-generation and in natural $R$. idaeus populations. If we estimate the percentage of individuals with a waxy bloom as compared with those without we obtain the ratio 24 : 3 or 88.9 and $11.1 \%$. In natural $R$. idaeus populations the corresponding percentages are 90.8 and 9.2. The numbers found in the $\mathrm{F}_{2}$-generation seem to indicate a segregation 15: 1 . This together with the gradual variation in the thickness of the waxy bloom indicate that the wild $R$. idaeus has at least two genes, cumulative in their action, which give rise to the waxy bloom. It is possible that the absence of the waxy bloom in $R$. arcticus depends on the action of the same genes.

The number of prickles in the wild $R$. idaeus varies greatly between the different populations. They represent all possibilities from almost prickleless to very abundantly aculeate. In the $\mathrm{F}_{2}$-generation the ratio between few prickles - abundant prickles was 11 : 16 or 40.7 and $49.3 \%$. In natural populations the corresponding percentages were 11.2 and 88.9 . The number of prickles is probably determined by several genes. The examination of the various $R$. idaeus populations gives the impression that certain characters linked with abundant prickles would have a selective value especially on very dry natural habitats.

In the wild the length and form of the prickles vary in the different $R$. idaeus populations. The prickles may be bent or straight. The straight prickles again are either thick or thin. In the $\mathrm{F}_{2}$-generation studied the prickles were exclusively fo the straight type. The ratio of the thin and thick prickles was $24: 3$ or 88.9 and $11.1 \%$. 
The inheritance of the prickle colour has been studied by CRANE and LAwRENCE (3) in cultivated $R$. idaeus varieties. This study has been completed by LEwIs (11). According to those papers the prickle colour is determined by two genes, the colour gene $\mathrm{T}$ and the gene $\mathrm{P}$ which intensifies the effect of $\mathrm{T}$. In the Finnish $R$. idaeus populations as well as in the $\mathrm{F}_{2}$-generation of the hybrid it has been found that the red colour of the prickles shows a greater variety of tinges than those mentioned by the above authors. The following colour shades may be distinguished: dark purple, purple, wine-colour, light wine-colour and green. In addition different types can be distinguished in which a part of the prickle is green while the prickle otherwise shows some of the red colours. If we classify the $\mathrm{F}_{2}$-individuals in accordance with CRANE and LAWRENCE rather summarily in that dark purple and purple are regarded as red, the other red colours as tinged and the two-coloured prickles as green, we obtain the following ratios: red 14, tinged 5 and green 5 or $58.4,20.8$ and $20.8 \%$. These values agree well with the theoretical values calculated according to CRANE and LAWrence (4), i.e. 13.5, 4.5 and 6.0. The corresponding percentages calculated from natural $R$. idaeus populations are $63.6,18.6$ and 17.8. The green prickled pt individuals which have at the same time yellow berries described by CRANE and LAWRENCE (3) have not been observed in the present material, although this type is known in wild $R$. idaeus plants in Finland. Neither has it been possible to distinguish a clear apricot-coloured PT type in the fruits.

Evidently the inheritance of prickle colour, especially in the wild $R$. idaeus forms needs reinvestigation. Obviously it is not so simple as the condition found in the cultivated varieties.

The inheritance of the flowering of the first year shoots follows the ratio 14 flowering: 13 not flowering in the $\mathrm{F}_{2}$-generation. In natural $R$. idaeus populations this character is rare, being, however, sometimes observed. In the present material the frequency of such individuals was $1.7 \%$.

Finally a few observations on the occurrence of the plant disease Didymella applanata common in raspberries may be presented. This fungus has never been found in $R$. arcticus. In the $\mathrm{F}_{1}$-generation some shoots were slightly affected. In the $\mathrm{F}_{2}$-generation unaffected individuals were found as well as individuals suffering to different extent from it. Since artificial infection experiments has not been carried out, it is impossible to decide whether real immunity is found in the $\mathrm{F}_{2}$-generation.

$$
\text { Discus sion. }
$$

As stressed by Stebbins (16) and Goodspeed (6) amongst others, chromosome pairing and chiasma formation in species hybrids may be regarded as fairly good criteria of the homology of the parental chromosomes. In this sense the chromosome complements of the taxonomically distinct species $R$. idaeus and $R$. arcticus, which differ in regard to a great number of clear characteristics, are to be held homologous to a great extent. A comparison with the meiosis the hybrid $R$. saxatilis $\times$ arcticus 
shows that these two species both of which belong to the section Cylactis, are less homologous in regard to their chromosome complements than $R$. arcticus and $R$. idaeus, which belongs to the section Idaeobatus. It seems prcbable that $R$. saxatilis, one of the parent species of this triploid hybrid, is autotetraploid. Chromosome conjungation occurs mainly in accordance with the theory of preferential pairing between the chromosomes derived from $R$. saxatilis which form homogenetic associations (cf. 17, p. 413). The trivalents are most probably composed of two saxatilis and one arcticus chromosome.

The degree of sterility in the hybrid $R$. idaeus $\times$ arcticus is difficult to estimate owing to the problematic seasonal sterility, and the good fertility shown by certain crosses. If we apply the biosystematic views of Clausen, Keck and Hiesey (1). $R$. idaeus and $R$. arcticus might be regarded even as two ecotypes belonging to the same ecospecies. On the basis of the present material it seems, however, safest to regard them as two ecospecies of one cenospecies. $R$. saxatilis seems similarly to be an ecospecies of the same cenospecies, since $R$. idaeus and $R$. saxatilis are able to hybridize (cf. 19).

The possibility that $R$. idaeus and $R$. arcticus may on the basis of their cytogenetic relationships be regarded as ecotypes, leads naturally in this case to a taxonomic absurdity. On the other hand it supports the opinion of Focke (5), founded on taxonomical reasons, that the section Cylactis is phylogenetically most closely related with the section Idaeobatus.

From the point of view of the speciation process the present case offers much interest. As shown by the morphological characters the differences between R.idaeus and $R$. arcticus depend on several genes. The study of the inheritance of several characters in the $\mathrm{F}_{2}$-generation of the hybrid gives rise, in spite of its incompleteness, to the assumption that many differences between those species depend on mutations of common allelomorphs. It is difficult to say in how far structural changes in chromosomes have been effective in speciation. From the occurrence of a small number of univalents it may be concluded in accordance with MüntZING's (13) Galeopsis hybrids, that such rearrangements have in fact taken place. Obviously the changed segments are, however, very small. In $R$. saxatilis $\times$ arcticus the presence of a few inversions is seen directly from the formation of bridges. In any case the speciation process in the three species under consideration seems to have occurred mainly through mutations. Structural changes have been very small, especially in $R$. idaeus $\times$ arcticus. The ability of the chromosomes to pair has therefore remained almost unchanged.

The causes of hybrid sterility have already been considered above. In R.saxatilis $\times$ arcticus it represents mainly different types of haplontic sterility. In R.idaeus $\times$ arcticus again the role played by haplontic sterility is difficult to estimate, as the effects of the seasonal sterility, characteristic of this hybrid, partly overlap it. In regard to causes of seasonal sterility the assumption has been proposed that it results from activity of the joint complex of idaeus and arcticus genes. This assumption is strongly supported by the sudden and complete restoration of fertility in the $\mathrm{F}_{1}$-generation. Crossing over and the anaphase segregation of chromosomes 
in the meiosis of the $\mathrm{F}_{1}$-hybrid destroy in most cases, the gene system leading to seasonal sterility, fertility being thus restored in $\mathrm{F}_{2}$-generation. The assumption that seasonal sterility depends on certain combination of the idaeus and arcticus genes is further supported by the fact that some $R$. idaeus strains give a fertile $\mathrm{F}_{1}$-generation.

For the elucidation of this problem many more crosses between different strains of $R$. idaeus and $R$. arcticus are needed. For the present the hypothesis may be put forward that a gene mutation or a small structural change in a chromosome that has given rise to seasonal sterility has been the first impulse to a different development of $R$. idaeus and $R$. arcticus. The development has continued mainly through gene mutations leading to great morphological differences, the pairing homology being, however, maintained. The wide circumpolar distribution of the parent species and the differentiation of $R$. idaeus into numerous distinct subspecies indicate that speciation has occurred relatively early, in any case before the pleistocene period, during which the connection between America and Eurasia was broken.

It is to be noted that spontaneous $R$. idaeus $\times$ arcticus hybrids are very rare in spite of the fact that these species, in Finland at least, often occur in the same habitats. The long flowering period of $R$. arcticus makes a simultaneous flowering of the species possible. Even artificial crossing is confronted with difficulties in that very few of the hybrid seeds germinate. The causes of this are unknown, but it is possible that the development of the hybrid embryo is not quite balanced. In the wild there is rarely the opportunity for such abundant crossing that a progeny would result.

\section{$S u m m$ ary.}

The subject of the study has been the $\mathrm{F}_{1}$ - and $\mathrm{F}_{2}$-generations of an artificial diploid Rubus idaeus $\times$ arcticus hybrid and the $\mathrm{F}_{1}$-generation of a spontaneous triploid $R$. saxatilis $\times$ arcticus hybrid. In these the meiosis in the PMC has been studied. In the $\mathrm{F}_{2}$-generation of the former hybrid observations on the inheritance of a number of species characters have been made.

The meiosis of the $\mathrm{F}_{1}$-generation in $R$. idaeus $\times$ arcticus is regular. In $83.4 \%$ of the divisions chromosome pairing is complete and 7 bivalents are formed. In $10.6 \%$ of the cells 6 bivalents and 2 univalents are observed. In $6.0 \%$ of the cells the division of one bivalent was irregular. In the meiotic divisions of the $\mathrm{F}_{2}$-generation no disturbances were observed.

In the meiosis of $R$. saxatilis $\times$ arcticus varying numbers of univalents, bivalents and trivalents are seen. The trivalents sometimes form inversion bridges and are delayed in their division. Some chromosomes are consequently eliminated and the chromosomes are divided unequally between the poles. The second division is more regular; sometimes, however, a few chromosomes are eliminated.

The $\mathrm{F}_{1}$-generation of $R$. idaeus $\times$ arcticus now studied is very sterile. In part this sterility depends on chromosomal irregularities. Mainly, however, it is caused 
by the fact that the anthers and the pollen suffer from drought during the summer and consequently no fertilization can take place. In autumn when the humidity of the air becomes higher, some fruit formation takes place. This sterility is here called seasonal sterility and it is thought to depend on an unfavourable gene combination formed by the idaeus and arcticus chromosome complements. In the $\mathrm{F}_{2}-$ generation fertility is restored owing to the breakdown of this combination. R.saxatilis $\times$ arcticus is completely sterile owing to irregular meiosis.

In the $\mathrm{F}_{2}$-generation of $R$. idaeus $\times$ arcticus a strong segregation of the species characters takes place. The observations indicate that the two species have a number of allelomorphs in common. It is assumed that the inheritance of some characters is connected with the action of several modifier genes.

It has been established that $R$. arcticus belonging to the Cylactis section of the genus Rubus and $R$. idaeus belonging to the Idaeobatus section have been derived from common ancestral forms at some time before the pleistocene period. The differentiation has probably been caused by a gene or chromosome mutation leading to seasonal sterility. Speciation has then continued mainly through gene mutations. Rearrangements in chromosome structure have been so small that the ability of the chromosomes to conjugate has not been changed.

I am greatly indebted to the Director of the State Horticultural Institute, Prof. Dr. O. Meurman, for good advice and criticism during the work.

\section{LITERATURE.}

(1) Clausen, J., Keck, D. D. and Hiesey, W. M. 1945. Experimental studies on the nature of species. II. Plant evolution through amphiploidy and autoploidy with examples from the Madinae. Carnegie Inst. Wash. Publ. N:o 564, p. 1-452.

(2) Crane, M. B. and Darlington, C. D. 1927. The origin of new forms in Rubus. I. Genetica, 9 , p. $241-278$.

(3) Crane, M. B. and Lawrence, W. J. C. 1931. Inheritance of sex, colour and hairiness in the raspberry, Rubus idaeus L. Journ. of Genetics, 24, p. 243-255.

(4) Fabergé, A. C. 1944. Genetics of the Scapiflora section of Papaver. III. Interspecific hybrids and genetic homology. Journ. of Genetics, 46, p. 125-149.

(5) Fоске, W. O. 1911-14. Species Ruborum. I-III. Stuttgart.

(6) Goodspeed, T. H. 1946 Meiotic prophase phenomena in species and interspecific hybrids of Nicotiana. Journ. Arn. Arboretum, 27, p. 453-469.

(7) Gustafsson, A. 1943. The genesis of European blackberry flora. Lunds Univ. Årskr. N.F., Avd. 2, 39, N:o 6, p. 1-199.

(8) Harland, S. C. 1936. The genetical conception of species. Biol. Rew., 11, p. 83-112.

(9) KüHL, O. 1937. Genanalyse bei Antirrhinum-Artbastarden. Z. ind. Abst. u. Vererb. lehre, 74, p. $125-160$.

(10) Lindberg, H. 1909. Formae duae hybridae generis Rubi novae e Finlandia. Medd. Soc. Fauna et Flora Fenn., 35, p. 141-144.

(11) LEWIS, D. 1939. Genetical studies in cultivated raspberries. I. Inheritance and linkage. Journ. of Genetics, 38, p. 367-379. 
(12) Müntzing, A. 1930. Outlines to a genetic monograph of Galeopsis. Hereditas, 13, p. 185-341:

(13) - 1938. Sterility and chromosome pairing in intraspecific Galeopsis hybrids. Hereditas, 24 , p. $117-188$.

(14) SaAstamoinen, S. 1931. Die nordische Himbeere (Rubus arcticus L.) in Finnland. Ann. Soc. Zool.-Bot. Fenn. Vanamo, 13, N:o 2, p. 355-414. (Finnish) Germ. summary.

(15) Silow, R. A. 1939. The genetics of leaf shape in diploid cottons and the theory of gene interaction. Journ. of Genetics, 38, p. $229-276$.

(16) Stebbins JR. G. L. 1945. The cytological analysis of species hybrids. II. Bot. Rew., 11, p. 463486.

(17) - - 1947. Types of polyploids: Their classification and significance: Adv. in Genetics, 1, p. $403-429$.

(18) Thomas, P. T. 1940. The origin of new forms in Rubus. III. The chromosome constitution of R. loganobaccus Bailey, its parents and derivatives. Journ. of Genetics, 40, p. 141-156.

(19) VaArama, A. 1939. Cytological studies on some Finnish species and hybrids of the genus Rubus L. Journ. Sci. Agr. Soc. Finland, 11, p. 72-85.

\title{
SELOST US
}

\section{SOLU- JA PERINNÖLLISYYSOPILLISIA HAVAINTOJA KAHDESTA MESI- MARJARISTEYTYMÄST Ä.}

\author{
ANTERO VAARAMA
}

Maatalouskoelaitoksen puntarhaosasto, Piikkiö.

Tutkimuksen kohteena on ollut kaksi mesimarjan risteytymää, nim. keinotekoisesti aikaansaatu vattu $\times$ mesimarja ja luonnonvarainen lillukka $\times$ mesimarja. Ensinmainitun $\mathrm{F}_{2}$-polvea on myös tarkasteltu.

Vaikka vattu ja mesimarja ovat systemaattisesti katsoen kaukana toisistaan, todetaan, että risteytymän kypsymisjaon kulku on hyvin säännöllinen. $83.4 \%$ :ssa siitepölyemosoluja ei ole mitään häiriöitä. $\mathrm{F}_{2}$-pclvessa on jako täysin säännöllinen. Sitävastoin lillukan ja mesimarjan risteytymällä on kypsymisjako paljon epäsäännöllisempi. Ensimmäisessä jaossa nähdään kromosomien muodostaneen, paitsi bivalentteja, myös uni- ja trivalentteja. Anafaasissa nähdään kromosomisiltoja, jotka osoittavat kromosomien sisältävän ylösalaisin kääntyneitä palasia, inversioita.

Kypsymisjaon säännöllisyydestä huolimatta vattu $\times$ mesimarja risteytymä on suureksi osaksi marto. Hedelmiä muodostuu jonkin verran vain kasvukauden lopulla, syys- lokakuussa. Tämän on tcdettu johtuvan siitä, että heteet ja siitepöly ovat arkoja kuivumiselle Kesällä siitepöly on kelvotonta, eikä hedelmöitystä voi tapahtua. Syksyllä, kun ilman kosteus on suurempi, voi kunnollista pölyä muodostua. Tämänlaatuista martoutta on nimitetty kausimartoudeksi. Sen perimmäisenä syynä on kantalajien kromosomien muodostama epäedullinen geeniyhdistelmä. $F_{2}$-polvessa palautuu hedelmällisyys melko täydelliseksi. Lillukan ja mesimarjan risteytymä on täysin marto, johtuen kypsymisjaon epäsäännöllisyyksistä.

Eräiden vatun ja mesimarjan ominaisuuksien periytymistä on tarkasteltu $\mathrm{F}_{2}$-polvesta tehtyjen havaintojen perusteella.

Vattu ja mesimarja ovat ilmeisesti kehittyneet yhteisestä kantamuodosta. Lajinkehitys on tapahtunut todennäköisimmin jo ennen pleistoseeniaikaa. Aiheen eri suuntiin käyvälle kehitykselle on antanut se geeni- tai kromosomimutaatio, jonka seurauksena on ollut kausimartous. Kehitys on sitten jatkunut pääasiassa geenimutaatioiden tietä. Hyvin pieniin palasiin kohdistuvia kromosomimutaatioita on ilmeisesti myös tapahtunut. Ne eivät ole kuitenkaan pystyneet häiritsemään kypsymisjaon kulkua. 